\title{
CHALLENGES FOR CONSTRUCTION OF HIGH VOLTAGE ELECTRICITY TRANSMISSION LINE IN NEPAL
}

\author{
Suraj Regmi \\ Assistant Manager \\ Project Management Directorate \\ Nepal Electricity Authority \\ Kathmandu Nepal
}

\author{
Anand Mandal \\ Electrical Engineer \\ Grid Development Department, Transmission Directorate \\ Nepal Electricity Authority \\ Kathmandu Nepal
}

\begin{abstract}
In recent years, generation of hydroelectric power is growing expressively in Nepal contributing more than $90 \%$ in national grid responsible for domestic requirement of electrical energy. Both private and stateowned utility and its subsidiaries contributing their output in national grid. In the coming future, generation of electricity will reach at the point having wet season energy in surplus after penetration of Upper Tamakoshi Hydropower Project (456 MW), largest installed capacity in national grid. Nepal Electricity Authority fully government owned utility for electricity disclosed information about different hydropower having combine installed capacity $2300 \mathrm{MW}$ already in different stages of development. However, the development of transmission line in the same pace has proven to be very difficult, creating hindrances in evacuation the power adequately despite of government effort. Despite the increment of investment in this sector, the progress has not been achieved as expected. High Voltage Transmission Line is one of the main reason that hinder to tap the abundant potential hydropower resources of Nepal. The main objective of this research is to identify the main hurdles to construct high voltage transmission line in the present perspective. This research work includes structured interviews and questionnaire survey conducted across stakeholders that included among others; client, consultant, contractor on five selected world bank financed electricity transmission line project to gather their opinions on hurdles of construction of power lines in Nepal. The fifteen key challenging factors was identified which were further ranked according to its Relative Importance Index (RII) in different perspectives in order to access challenges associated with construction of transmission line.
\end{abstract}

Keywords - High Voltage Transmission, Transmission Projects, Relative Importance Index, Construction, Nepal

\section{INTRODUCTION}

Despite the tremendous hydropower potential, the nature has gifted, Nepal is still not being able to harness the benefits due to which Nepal has still been relying upon its south neighbor India for fulfillment of its domestic energy demand. Among the many reasons that contribute to the slow pace of hydropower development in Nepal, the lack of high capacity transmission line across and along the far-flung areas of major river basin stands at top. This has hindered to a large extent to prosper in the power generation as there is uncertainty that the power generated by them could be evacuated to the load centers. It is necessary to develop robust transmission system of high voltage level to evacuate the power from the planned and under construction project. Infrastructure for evacuation of electrical power is insufficient affecting the overall development of hydropower in Nepal [1]. Nepal lacks transmission capacity for internal evacuation of power and export purpose (ADB). Several studies have identified challenges of construction of transmission line in Nepal. Major challenges to the timely completion of transmission line projects includes NEA's centralized and prolonged procurement process, weak contractors, the absence of consultant to support project implementation, land acquisition and forest clearance issues (MoF,2015) [2]. Gill concluded that actual construction of large transmission line be completed in a year or two but due to complexities involved in the approval procedure and opposition from various groups it can take years to build line and, in some case, projects are stopped altogether [3]. Dubey, identified under performance, fuel availability, problems of coal blocks, equipment shortage, land acquisition and environmental clearance, manpower shortage of Indian electricity sector [4]. D. King, assessed that they have significant effect on environment, involvement of a team of hired specialist in design construction disciplines and involvement of many stakeholders, such as environmental and community group etc. are reason of poor project management performance [5]. 


\section{International Journal of Engineering Applied Sciences and Technology, 2020 \\ Vol. 5, Issue 7, ISSN No. 2455-2143, Pages 46-52 \\ Published Online November 2020 in IJEAST (http://www.ijeast.com)}

High Voltage transmission lines are necessary for evacuating the power from generating stations to the various distributions unit then eventually to the consumers' home, industries etc [6]. Nepal Electricity Authority (NEA) is responsible for developing and operating Nepal's high-voltage transmission line system, by public as well as private hydropower generation projects [7]. However, construction of power lines has been sluggish. More than 60 transmission lines with various voltage level (including $66 \mathrm{kV}, 132 \mathrm{kV}, 220 \mathrm{kV}$ and $400 \mathrm{kV}$ ) are being constructed in the country, of which only 30 projects are completed [8]. The country does not yet have enough high-voltage transmission lines to transmit electricity and incapability to construct transmission lines has negatively affected hydropower development, as investors worry about projects financial viability if they are unable to supply electricity to load centers. Already, power generation has outpaced the capacity of the grid, resulting in spill of electrical energy. The severe cost time overrun in transmission line project due to the hurdles motivated this research work to assess the different challenging factor in the transmission line construction industry and propose possible remedies to improve this awful situation.

This research works covers the World Bank financed transmission line project implemented by Nepal Electricity Authority with capacity of $132 \mathrm{kV}$ or above. The projects under study located in eastern, central and western of Nepal. The main motives on choice of project for this study based on three main factors: i) all the projects are national priority projects of Government of Nepal having strategic importance because they can make possible future power trade with India and Bangladesh. ii) all the projects are under construction having team of multiple stakeholders like client, consultant, contractor and iii) all of these projects received the loan assistance from World Bank with high level of investment in them; the implementing agency are under pressure to complete on time, within budget, and to the desired quality to get return for investment and to pay back the loan.

Table1: List of Projects

\begin{tabular}{|c|c|c|c|}
\hline $\begin{array}{l}\text { S. } \\
\text { N. }\end{array}$ & Projects Name & $\begin{array}{c}\text { Starting } \\
\text { date (AD) }\end{array}$ & $\begin{array}{l}\text { Project } \\
\text { Status }\end{array}$ \\
\hline 1 & $\begin{array}{l}\text { Hetauda -Dhalkebar- } \\
\text { Duhabi 400kV TL } \\
\text { Project }\end{array}$ & 2011 & $\begin{array}{l}\text { Under } \\
\text { Construction }\end{array}$ \\
\hline 2 & $\begin{array}{l}\text { Khimti -Dhalkebar } \\
\text { 220kV TL Project }\end{array}$ & 2004 & \\
\hline 3 & $\begin{array}{l}\text { Hetauda -Bharatpur } \\
220 \mathrm{kV} \text { TL Project }\end{array}$ & 2009 & $\begin{array}{l}\text { Under } \\
\text { Construction }\end{array}$ \\
\hline 4 & $\begin{array}{c}\text { Bharatpur - } \\
\text { Bardaghat 220kV } \\
\text { TL Project }\end{array}$ & 2011 & $\begin{array}{l}\text { Under } \\
\text { Construction }\end{array}$ \\
\hline 5 & $\begin{array}{l}\text { Kabeli Corridor } \\
\text { 132kV TL Project }\end{array}$ & 2008 & $\begin{array}{c}\text { Under } \\
\text { Construction }\end{array}$ \\
\hline
\end{tabular}

Source: NEA Annual Report, 2019

\section{RESEARCH METHODOLOGY}

\section{A. Data Collection}

The data has been collected from different sources. The primary data was obtained through the responses of representatives of project stakeholder's employer, consultant, and contractor by sending the same questionnaire. The Secondary data from NEA year book, EIA/IEE report of the concerned project, RAP, SIA VCDP reports of concerned project.

\section{B. Instrument of Data Collection}

The instrument used for collecting the data was questionnaire. The questionnaires were given to potential respondents either personally and in in most cases through e-mail by developing it in Google form. The questionnaire consisted of thirty -nine close-ended questions and grouped under five different categories namely client related, consultant related, contractor related, prevailing policies related to Government of Nepal and social/political geological related. The questionnaire was designed in such a way as to get high response rate from respondents. Only closed-ended questions and Liker't Scale (1 to 5 where 1 stand for strongly disagree and 5 for strongly agree). Respondent were requested to indicate which factor they considered to have significant challenge based on their experience and other factors. A pilot study conducted with an experienced person in the construction of transmission line who was asked to critically review the design and structure of the questionnaire, to ensure that the questionnaire will serve its purpose when distributed to stakeholders in the project namely, client, contractors and consultants.

A total of 65 respondents constituted the sample size. Sixty (65) questionnaires developed in Google form were sent to identified respondent through their respective email out of these; fifty-five (55) were returned which represents $84.61 \%$.

\section{Method of Data Analysis}

Data generated from the field survey was analyzed from different aspects. The research design has incorporated difficult categories of factor during the study. The software tools used for the analysis are mainly Microsoft Excel and SPSS. After the data was collected it was edited for completeness, homogeneity and accuracy. The findings collected from primary and secondary data was analyzed. The data are analyzed to find frequency distributions, means, standard deviation, reliability analysis, concordance of data etc. The qualitative data obtained from questionnaire survey was analyzed by comparing the opinions of client, consultant and contractor with reference to facts and figures obtained from secondary data.

Both descriptive and inferential statistics shall be used in data analysis. Statistical test and methods as listed below shall be done in analysis. 


\section{International Journal of Engineering Applied Sciences and Technology, 2020 \\ Vol. 5, Issue 7, ISSN No. 2455-2143, Pages 46-52 \\ Published Online November 2020 in IJEAST (http://www.ijeast.com)}
a) Relative Importance Index
b) Kendall's Coefficient of Concordance
c) Reliability Analysis using Cronbach's Alpha

\section{Relative Importance Index}

The aim of the analysis was to establish the relative importance of the various factors identified as responsible for challenges for construction of high voltage transmission line in Nepal. The score for each factor is calculated by summing up the scores given to it by the respondents. The relative importance index (RII) was calculated using the following formula [9].

$$
R I I=\frac{\sum P i}{N . n} \ldots \ldots \ldots \ldots \ldots \ldots \ldots
$$

Where,

$$
\begin{aligned}
& \mathrm{RII}=\text { relative importance index } \\
& P i=\text { respondent's rating on questionnaire } \\
& \mathrm{N}=\text { sample size } \\
& \mathrm{n}=\text { the highest attainable score on cause of } \\
& \text { challenges of construction }
\end{aligned}
$$

The relative importance index for all the challenges factors and groups was calculated using the equation (1) above. The indexes were ranked for Clients (Employer), Contractors and Consultants.

\section{Kendall's Coefficient of Concordance}

Kendall's coefficient of concordance, represented by the symbol W, is an important non-parametric measure of relationship [10]. It is used for determining the degree of association among several $(\mathrm{k})$ sets of ranking of $\mathrm{N}$ objects or individuals. Kendall's coefficient of concordance (W) is considered an appropriate measure of studying the degree of association among three or more sets of rankings [11]. This descriptive measure of the agreement has special applications in providing a standard method of ordering objects according to consensus when we do not have an objective order of the objects [12]. The procedure for computing and interpreting Kendall's coefficient of concordance $(W)$ is as follows:

(a) All the objects, $N$, should be ranked by all $k$ judges in the usual fashion and this information may be put in the form of a $k$ by $N$ matrix;

(b) For each object determine the sum of ranks $(\bar{R} j)$ assigned by all the $k$ judges;

(c) Determine and then obtain the value of $s$ as under:

$$
s=\sum\left(R_{j}-\overline{R_{\jmath}}\right)^{2}
$$

(d) Work out the value of $W$ using the following formula:

$$
w=\frac{s}{\frac{1}{12}\left(N^{3}-N\right) k^{2}}
$$

Where,

$s=\sum(R j-\overline{R j})^{2}$;

$k=$ no. of sets of rankings i.e., the number of judges;
$N=$ number of objects ranked;

$\frac{s}{\frac{I}{12}\left(N^{3}-N\right) k^{2}}=$ maximum possible sum of the squared deviations i.e., the sum $s$ which would occur with perfect agreement among $k$ rankings.

In the current analysis, the calculation of Kendall's coefficient of concordance was calculated using a software SPSS.

\section{Reliability Analysis using Cronbach's Alpha}

Cronbach's coefficient alpha " $\alpha$ " was used to test the reliability of five point scale used in the survey. The acceptable lower limit for Cronbach's alpha is usually considered to be 0.7 , although values as low as 0.6 are sometimes acceptable for exploratory research [13]. Cronbach's (alpha) is used as a (lower bound) estimate of the reliability of a psychometric test. It has been proposed that alpha can be viewed as the expected correlation of two tests that measure the same construct. By using this definition, it is implicitly assumed that the average correlation of a set of items is an accurate estimate of the average correlation of all items that pertain to a certain construct.

Cronbach's alpha will generally increase as the inter correlations among test items increase, and is thus known as an internal consistency estimate of reliability of test scores [14]. Mathematically, reliability is defined as the proportion of the variability in the responses to the survey that is the result of differences in the respondents. That is, answers to a reliable survey will differ because respondents have different opinions, not because the survey is confusing or has multiple interpretations.

From reliability analysis, it can be determined that the extent to which the items in questionnaire are related to each other, can get an overall index of the repeatability or internal consistency of the scale as a whole. Alpha (Cronbach) model is used in this research to measure reliability. The computation of Cronbach's alpha is based on the number of items on the survey $(\mathrm{k})$ and the ratio of the average inter-item covariance to the average item variance [15].

The standardized Cronbach's alpha can be defined as

$$
\alpha=\frac{k \bar{c}}{(\bar{v}+(k-1) \bar{c})}
$$

$k$ is number of items,

$\bar{v}$ is number of items the average variance of each component (item),

$\bar{c} \bar{c}$ the average of all co variances between the components across the current sample of items (that is, without including the variances of each component).

In this research, the calculation of Reliability analysis of 5point psychometric test i.e like art scale which using Cronbach's alpha was calculated using a software SPSS. This will show the average reliability of this research. 


\section{$D$. Population of the study}

The five-transmission line project financed by World Bank implemented being by Nepal Electricity Authority has been taken into consideration. From the data obtained about the allocated position of different technical officer level staffs, the selection of respondent was done keeping in mind who can understand the questionnaire and can response accordingly have related to their project. It was found that the population size was nearly about 56 . The data about currently working technical level staffs of client and consultant have been collected from the reliable source. Table 2 depicts the distribution of employee of client, consultant and contractor of different projects of NEA.

Table 2: Technical Officer Level Staff Deputed in Project

\begin{tabular}{|c|c|c|c|c|}
\hline Projects & Client & Consultant & Contractor & Total \\
\hline $\begin{array}{c}\text { Hetauda - } \\
\text { Dhalkebar- } \\
\text { Duhabi 400 } \\
\text { KV TLP }\end{array}$ & 7 & 5 & 4 & 16 \\
\hline $\begin{array}{c}\text { Khimti - } \\
\text { Dhalkebar } \\
220 \text { KV TLP }\end{array}$ & 5 & 4 & 4 & 13 \\
\hline $\begin{array}{c}\text { Hetauda - } \\
\text { Bharatpur } \\
220 \text { KV TLP }\end{array}$ & 5 & 4 & 3 & 12 \\
\hline $\begin{array}{c}\text { Bharatpur - } \\
\text { Bardaghat } \\
220 \text { KV TLP }\end{array}$ & 5 & 4 & 3 & 12 \\
\hline $\begin{array}{c}\text { Kabeli } \\
\text { Corridor 132 } \\
\text { KV TLP }\end{array}$ & 5 & 3 & 4 & 12 \\
\hline Total & $\mathbf{2 7}$ & $\mathbf{2 0}$ & $\mathbf{1 8}$ & $\mathbf{6 5}$ \\
\hline
\end{tabular}

\section{E. Sampling Size Techniques}

Sample Size for infinite population is calculated as follows:

$$
\text { Sample Size }=\quad \text { Where, }
$$

$$
\frac{\mathrm{Z}^{2} \mathrm{x}(\mathrm{p}) \mathrm{x}(1-\mathrm{p})}{\mathrm{c}^{2}}
$$

$\mathrm{Z}=\mathrm{Z}$ value (e.g. 1.96 for $95 \%$ confidence level) $\mathrm{p}=$ percentage of chances that questionnaire depicts the causes of delay, expressed as decimal (0.5 used for sample size needed) $\mathrm{c}=$ confidence interval, expressed as decimal

(e.g.: $.05= \pm 5)$

$=1.96^{2} \mathrm{X} 0.5^{*} 0.5 / 0.05^{2}$

$=384.16$

Sample size for finite population is calculated using correction as follows:

New sample size $=(($ Sample size $) /((1+($ Sample size -1$) /$ pop)))

$$
=((384.16) /(1+384.16-1) / 65)))=54.12
$$

From the above calculation, it was found that minimum size of sample required was 54.12, and the data obtained from the questionnaire response was 55 in number which is just sufficient. Purposive sampling technique was applied for this study in order to get the actual targeted population.

\section{RESULT AND DISCUSSION}

\section{A. Analysis and Presentation of Challenges based on Relative Importance Index (RII)}

After analyzing the data following results has been found based on questionnaire survey with projects stakeholders. The below table shows the top fifteen challenging factors for the construction of high voltage electricity transmission line in

\begin{tabular}{|c|c|c|c|c|c|c|c|}
\hline \multirow{2}{*}{$\begin{array}{l}\mathbf{S} \\
\mathbf{N}\end{array}$} & \multirow[t]{2}{*}{ Challenges } & \multicolumn{2}{|c|}{$\begin{array}{l}\text { Employer's } \\
\text { View }(n=27) \\
\end{array}$} & \multicolumn{2}{|c|}{\begin{tabular}{|l|} 
Consultant's \\
View $(n=17)$ \\
\end{tabular}} & \multicolumn{2}{|c|}{$\begin{array}{l}\text { Contractor's } \\
\text { View }(n=11)\end{array}$} \\
\hline & & RII & Rank & RII & Rank & RII & Rank \\
\hline 1 & $\begin{array}{l}\text { Lengthy difficult } \\
\text { provision related } \\
\text { to forest clearance }\end{array}$ & 0.436 & 1 & 0.261 & 3 & 0.189 & 2 \\
\hline 2 & $\begin{array}{l}\text { Lack of timely } \\
\text { site possession }\end{array}$ & 0.403 & 6 & 0.287 & 1 & 0.192 & 1 \\
\hline 3 & $\begin{array}{l}\text { Cash flow } \\
\text { financial } \\
\text { difficulties faced } \\
\text { by contractor }\end{array}$ & 0.429 & 2 & 0.232 & 11 & 0.163 & 8 \\
\hline 4 & $\begin{array}{l}\text { High Turnover of } \\
\text { Project Manager }\end{array}$ & 0.36 & 13 & 0.283 & 2 & 0.167 & 5 \\
\hline 5 & $\begin{array}{l}\text { High expectation } \\
\text { of local people } \\
\text { from the project }\end{array}$ & 0.418 & 3 & 0.203 & 17 & 0.16 & 9 \\
\hline 6 & $\begin{array}{l}\text { Difficult Provision } \\
\text { to implement } \\
\text { IEE/EIA }\end{array}$ & 0.385 & 7 & 0.254 & 5 & 0.138 & 24 \\
\hline 7 & $\begin{array}{l}\text { Long gap between } \\
\text { project } \\
\text { identification } \\
\text { construction due } \\
\text { to financial clos } \\
\text { bidding process }\end{array}$ & 0.367 & 12 & 0.247 & 8 & 0.16 & 9 \\
\hline 8 & $\begin{array}{l}\text { Lack of adequate } \\
\text { experience of } \\
\text { project staff on } \\
\text { similar filed }\end{array}$ & 0.341 & 25 & 0.25 & 7 & 0.174 & 4 \\
\hline 9 & $\begin{array}{l}\text { Ambiguous } \\
\text { provision of } \\
\text { compensation } \\
\text { for RoW of TL } \\
\text { in Electricity } \\
\text { Regulation, }\end{array}$ & 0.407 & 5 & 0.189 & 20 & 0.167 & 5 \\
\hline 10 & $\begin{array}{l}\text { Poor Contract } \\
\text { management } \\
\text { project } \\
\text { administration }\end{array}$ & 0.396 & 8 & 0.229 & 22 & 0.160 & 11 \\
\hline
\end{tabular}
Nepal.

Table 3: Top Fifteen major challenging factors 
International Journal of Engineering Applied Sciences and Technology, 2020

Vol. 5, Issue 7, ISSN No. 2455-2143, Pages 46-52

Published Online November 2020 in IJEAST (http://www.ijeast.com)

\begin{tabular}{|c|l|l|l|l|l|l|l|}
\hline & capacity of NEA & & & & & & \\
\hline 11 & $\begin{array}{l}\text { Lack of timely } \\
\text { approval on } \\
\text { design, drawing } \\
\text { and estimates }\end{array}$ & 0.360 & 13 & 0.221 & 13 & 0.178 & 3 \\
\hline 12 & $\begin{array}{l}\text { Lack of timely } \\
\text { decision making } \\
\text { by client on } \\
\text { pertinent issues }\end{array}$ & 0.338 & 26 & 0.254 & 5 & 0.156 & 12 \\
\hline 13 & $\begin{array}{l}\text { Public opposition } \\
\text { by putting } \\
\text { irrational demand }\end{array}$ & 0.414 & 4 & 0.167 & 27 & 0.156 & 12 \\
\hline 14 & $\begin{array}{l}\text { Difficult Rugged } \\
\text { topography }\end{array}$ & 0.338 & 26 & 0.261 & 3 & 0.127 & 29 \\
\hline 15 & $\begin{array}{l}\text { Incompetent } \\
\text { subcontractor }\end{array}$ & 0.370 & 10 & 0.200 & 18 & 0.149 & 18 \\
\hline
\end{tabular}

\begin{tabular}{|l|l|l|l|l|}
\hline & $\begin{array}{l}\text { Social/Political } \\
\text { Geograhy }\end{array}$ & & & \\
\hline & Total & & $\mathbf{3 9}$ & $\mathbf{2 9 . 1 6 4}$ \\
\hline
\end{tabular}

Average Reliability $=\sum \alpha i X n i ~ / \sum n i=29.164 / 39=0.747$

\section{B. Analysis of Reliability of the Finding of the Study Using Kendall's Coefficient of Concordance}

Kendall's coefficient of concordance, is an important nonparametric measure of relationship $\mathrm{W}$ ranges from 0 (no agreement) to 1 (complete agreement). The data obtained were ranked according to the value of Relative Importance Index. The ranking of challenges of client's view, consultant's view, contractor's view and overall view were made. And the Kendall's coefficient of concordance was calculated using software tool SPSS.

Table 3 shows the employer's, consultant's and Contractor's view of the respondents of challenges of construction of transmission line project by NEA.

\section{A. Analysis and Presentation of Challenges based on Relative Importance Index (RII)}

All the response from the lient, consultant, and contractor were combined to measure the internal consistencies of each question of questionnaire. Similarly, the highest value of coherence was obtained questionaire related to contractor which was 0.792 . These fall within the acceptable value considered for a research instrument's reliability. The lowest value of coherence was obtained for questionire related to consultant 0.556 i.e. challenges related to consultant of a value of 0.556 which is slightly less than acceptable value of 0.6. Since, it is slightly less than the acceptable value, the average of Cronbach's coefficient alpha was calculated to determine the overall consistencies of the questions. The average value of Cronbach's alpha was calculated as follows:

$$
\text { Average Reliability }=\frac{\sum \text { aixni }}{\sum \text { ni }}=0.747
$$

Since the average value of coefficient of alpha is more than 0.7 ie 0.747 , the questions are acceptable and the overall reliability of the questionnaire is good.

Table 4: Reliability analysis of the finding using Cronbach's $\alpha$

\begin{tabular}{|c|l|c|c|c|}
\hline $\begin{array}{c}\mathbf{S} \\
\mathbf{N}\end{array}$ & \multicolumn{1}{|c|}{$\begin{array}{c}\text { Questionaire } \\
\text { Group }\end{array}$} & $\begin{array}{c}\text { Cronbach' } \\
\text { s Alpha ai }\end{array}$ & $\begin{array}{c}\text { No of } \\
\text { Items, } \\
\mathbf{n i}\end{array}$ & $\mathbf{\alpha i} \mathbf{X ~ n i}$ \\
\hline 1. & $\begin{array}{l}\text { Questionaire } \\
\text { related to Client }\end{array}$ & 0.772 & 14 & 10.808 \\
\hline 2. & $\begin{array}{l}\text { Questionaire related } \\
\text { to Consultant }\end{array}$ & 0.556 & 5 & 2.780 \\
\hline 3. & $\begin{array}{l}\text { Questionaire related } \\
\text { to Contractor }\end{array}$ & 0.792 & 11 & 8.712 \\
\hline 4. & $\begin{array}{l}\text { Questionaire related } \\
\text { to Prevailing Polices } \\
\text { of GoN }\end{array}$ & 0.742 & 4 & 2.968 \\
\hline 5. & $\begin{array}{l}\text { Questionaire } \\
\text { related to }\end{array}$ & 0.782 & 5 & 3.910 \\
\hline
\end{tabular}

The value of correlation was found to be of minimum value at 0.189 between Clients and Consultant 's rank value, which is fairly acceptable because of positive corelation. Similarly, the value of correlation was found to be of maximum value at 0.630 between overall ranking and consultant's ranking.

Table 5: Analysis of Reliability of Finding of the Study Using Kendall's Coefficient of Concordance

\begin{tabular}{|l|l|c|c|c|c|}
\hline S & \multirow{2}{*}{ Rank } & \multicolumn{3}{|c|}{ Pearson Correlation (Kendall's Tau_b) } \\
\cline { 3 - 6 } & & Client & Consultant & Contractor & Overall \\
\hline 1. & Client & 1 & 0.189 & 0.330 & 0.538 \\
\hline 2. & Consultant & 0.189 & 1 & 0.310 & 0.630 \\
\hline 3. & Contractor & 0.330 & 0.310 & 1 & 0.541 \\
\hline 4. & Overall & 0.538 & 0.630 & 0.541 & 1 \\
\hline
\end{tabular}

\section{Discusssion}

The study reveals that one of the major challenges of construction of high voltage transmission line in Nepal is forest clearance procedure RII (0.887) which is ranked first (Rank =I) position in this study. It is found that forest clearance in Nepal is a tedious job and time-consuming process as it follows complicated procedures requiring clearance from a number of layers in the Ministry of Forests and Environment and its subordinate offices. The prevailing policies related to forest clearance in Nepal seems very rigid, thus it is required to policy lax for smooth construction of development projects.

Similarly, the study reveals that another major challenge is lack of timely site possession for construction of tower pad $(\mathrm{RII}=0.883)$ which is ranked in second (Rank =II) position in this study. Land acquisition for electricity transmission line poses an increasingly significant challenge in Nepal. Utilities are fronting major constraint and delays regarding the availability of site for construction. There is significant mismatch of expectation from the project affected people (PAP). Stakeholder and other land owner may collectively oppose the project construction. In such case, it is essential to proactively manage the land owner's expectation. 


\section{International Journal of Engineering Applied Sciences and Technology, 2020 \\ Vol. 5, Issue 7, ISSN No. 2455-2143, Pages 46-52 \\ Published Online November 2020 in IJEAST (http://www.ijeast.com)}

Next, Non-Performance and cash flow financial difficulties faced by the contractor pad $(\mathrm{RII}=0.883)$ which is ranked in second (Rank =II) position. The study found that the project suffers from unsatisfactory contractor performance showing their cash flow and financial condition which has been ranked third $($ Rank $=$ III). This refers to contractor inability to fulfill its responsibilities as per schedule due to an apparent lack of interest. This study shows that the competency of the selected contractor and non-performance of the contractor is one of the major challenges for construction of high voltage transmission lines.

Similarly, frequent transfer (turnover) of key project staff and project manager due to political reason another challenge (RII=0.810) Rank (IV). It is quite difficult to have capacity development not only for the people but also for the institution where key official (project manager) transferred in quick time, even small get affected by this quick transfer. It is not a good symptom for project at least key project official should be retained until the completion.

Furthermore, high expectation of people from the project is another finding of the study (RII=5) $\operatorname{Rank}(\mathrm{V})$. Due to communication gap between project and local resident demand the public infrastructure project like road, water supply, irrigation from the project. But the project has limited funding for such type of activity. Construction of road, water supply, irrigation project has separate line agencies. Therefore, project officials convince them about their demand.

Likewise, difficult provision of Initial Environment Examination (IEE)/Environmental Impact Assessments seems another challenging factors $(\mathrm{RII}=0.778)$ Rank $(=\mathrm{VI})$ shows by this study. In IEE/EIA there is very stringent provision about compensatory plantation. If project cut down one tree twentyfive trees must be as a compensation.

On the other hand, there were thirty- seven (37) under five categories, challenges having $\mathrm{RII}<0.6$ considered insignificant. These challenges are considered least significant, they are, Over staffing on the project leading the disturbance of project management team (RII=0.472) Rank (=XXXVII), poor financial health of client (RII=0.497) Rank (=XXXVI), Improper (Inappropriate) methods by contractor (RII=) Rank (=XXXV), lack of budget for land purchase and Right of Way compensation distribution (RII= 0.589) Rank (=XXXIV).

\section{CONCLUSION AND RECCOMENDATION}

It is evident that deficit in adequate transmission line capacity of Integrated Nepalese Power system (INPS) resulted in impede to tap the abundant hydropower potential of Nepal. Based on the results and finding of this study, the table below summarizes the key challenges and their possible solution are recommended for successfully achieving the implementation of expanding electricity transmission plans of Government of Nepal.

\begin{tabular}{|c|c|}
\hline Key challenges & Possible Remedies \\
\hline $\begin{array}{l}\text { Issues of Land } \\
\text { acquisition, } \\
\text { Right of way, } \\
\text { Forest clearance } \\
\text { resettlement }\end{array}$ & $\begin{array}{l}\text { Supportive legal regulatory framework } \\
\text { is needed to introduce to resolve the issues } \\
\text { of Land acquisition as well as Forest } \\
\text { clearance and resettlement by the executing } \\
\text { agency } \\
\text { Inter-ministerial co-ordination } \\
\text { committee should be formed at joint } \\
\text { secretary level to facilitate land acquisition, } \\
\text { Right of Way, resettlement and forest } \\
\text { clearance } \\
\text { By Pro-actively managing the } \\
\checkmark \text { landowner's expectation. } \\
\text { Policy lax needed by removing the } \\
\text { stringent provision related to forest } \\
\text { clearance and IEE/EIA }\end{array}$ \\
\hline $\begin{array}{l}\text { Non - } \\
\text { Performance, } \\
\text { Cash flow } \\
\text { financial } \\
\text { difficulties } \\
\text { faced by the } \\
\text { contractor }\end{array}$ & $\begin{array}{l}\text { Client should very aware about the } \\
\text { progress of project and closely monitor the } \\
\text { schedule submitted by contractor. } \\
\text { Immediate action should be taken project } \\
\text { management for delay execution of work if } \\
\text { any } \\
\text { Contractor should pay the particular } \\
\text { attention to the project during the pre- } \\
\text { contract \& bidding so as to go for } \\
\text { implementation that they have competitive } \\
\text { advantage } \\
\text { Contractor should make certain that } \\
\text { they have enough cash flow to execute the } \\
\text { works and stop the practice of diverting } \\
\text { particular moneys to other sector to avoid } \\
\text { being cash shortfall during the project } \\
\text { execution } \\
\text { Contracting company should ensure } \\
\text { that they have adequate experience to } \\
\text { execute the assignment, set up competent } \\
\text { team in the site and use appropriate } \\
\text { construction methods for the required } \\
\text { scope of works }\end{array}$ \\
\hline $\begin{array}{l}\text { Political } \\
\text { Interference for } \\
\text { frequent transfer } \\
\text { of Key project } \\
\text { staff experience } \\
\text { Project Manager }\end{array}$ & $\begin{array}{l}\text { The key staff of project and Project } \\
\text { manager should be retained on project until } \\
\text { the completion }\end{array}$ \\
\hline $\begin{array}{l}\text { Lack of } \\
\text { adequate } \\
\text { experience of } \\
\text { project staff }\end{array}$ & $\begin{array}{l}\text { Outsource the design consultant, } \\
\text { supervision engineers, procurement } \\
\text { specialist and safeguard expert by the client }\end{array}$ \\
\hline $\begin{array}{l}\text { Poor Contract } \\
\text { management } \\
\text { project } \\
\text { administration }\end{array}$ & $\begin{array}{l}\quad \text { Enhance the capacity of engineers of } \\
\text { NEA and project manager }\end{array}$ \\
\hline
\end{tabular}




\begin{tabular}{|c|c|}
\hline capacity of NEA & \\
\hline $\begin{array}{l}\text { Poor } \\
\text { communication } \\
\text { between } \\
\text { projects and } \\
\text { stakeholder }\end{array}$ & $\begin{array}{l}\text { Enhance the public information about } \\
\text { the projects which will ultimately improve } \\
\text { transparency. }\end{array}$ \\
\hline
\end{tabular}

\section{REFERENCE}

[1] Shakya S. (2016). Nepal Portfolio Performance Review: Energy Sector, Ministry of Finance, Nepal Government, (pp. 65-72).

[2] Nepal: Energy Sector Overview" (2016); http//www.sarienergy.org/pagefiles/countries/Nepal energy detail.asp

[3] Gill R.S. (2005). Electric Transmission Line Routing Using a Decision Landscape Based Methodology, M. Sc. Thesis, Wichita State University.

[4] Dubey D.K. (2018). Issues and challenges in electricity sector in India, International conferences on Issues Emerging Economics (ICIEE), The Business \& Management Review, Vol. 5, No. 4, (pp. 132-139).

[5] Truman D. K. (2018). Assessment of problems associated with poor project management performance, Long International, Inc.

[6] Goutom K., Adrian J. and Martin S. (2016). Comprehensive review of delays in power transmission projects. IET Generation Transmission \& Distribution. 10. 10.1049/iet-gtd.2016.0376.

[7] Anand Mandal and Mahmud Abdul Matin Bhuiyan (2014). Optimum use of renewable energy resources to generate electricity via hybrid systems, Int. J. Renewable Energy Technology, Vol. 5, No. 4, (pp. 299-309).

[8] Nepal Electricity Authority, Kathmandu, Nepal, Annual Report 2018-2019.

[9] Fagbenle 0. I., Adeyemi A. Y. and Adesanya D. A. (2004). The Impact of Non-Financial Incentives on Bricklayers' Productivity in Nigeria, Construction Management and Economics, 22(9), (pp. 809-911).

[10] Yarnold, Paul. (2014). UniODA vs. Kendall's Coefficient of Concordance (W): Multiple Rankings of Multiple Movies, Optimal Data Analysis. 3, (pp. 121-123).

[11] Lewis, Gordon H., and Richard G. Johnson (1971). Kendall's Coefficient of Concordance for Sociometric Rankings with Self-Excluded Sociometry, JSTOR, Vol. 34, no. 4, (pp. 496-503).

[12] Amanda G., D. Terrance B., Kevin S. and Christopher S. (2013), Use of Kendall's coefficient of concordance to assess agreement among observers of very high-resolution imagery, Geocarto International, Vol 28:6, pp. 517-526.

[13] Hair, J.F., Black, W.C., Babin, B.J., \& Anderson, R.E. (2010). "Multivariate Data Analysis", Seventh Edition, Prentice Hall, Upper Saddle River, New Jersey.
[14] Taber, K.S. (2018). The Use of Cronbach's Alpha When Developing and Reporting Research Instruments in Science Education, Res Sci Educ 48, (pp. 1273-1296).

[15] Gliem J.A. and Gliem R.R. (2003). Calculating, Interpreting and Reporting Cronbach's Alpha Reliability Coefficient for Likert-Type Scales, Midwest Research to Practice Conference in Adult, Continuing and Community in Education, The Ohio State University, Columbus, Oct., (pp. 82-88). 